FACTA UNIVERSITATIS

Series: Economics and Organization Vol. 17, $\mathrm{N}^{\mathrm{o}} 2$ 2, 2020,pp. 157 - 172

https://doi.org/10.22190/FUEO191223012S

Original Scientific Paper

\title{
THE RELATIONSHIP BETWEEN POPULATION AGEING AND MEDICAL EXPENDITURES IN ROMANIA
}

\author{
UDC 316.346.32:[657.474:615.2(498)
}

Lucian Adrian Sala*

University of Craiova, Romania

\begin{abstract}
With recent developments in the medical field and faster access to medical professional and healthcare services providers, accompanied by better education and a higher level of hygiene, life expectancy for both males and females in Romania is increasing at a steady pace. From a medical point of view, this is a remarkable accomplishment when compared with past decades when the average life expectancy was much lower than in recent times. A longer life span will automatically, for the most part, have the unwanted effect of increasing spending on medical services on behalf of the state to ensure a better quality of life for the elderly. Therefore, the public health system will be placed under additional pressure on behalf of healthcare providers to offer higher quality services to the elderly. This paper aims to explore the degree of influence that age and income have on the growing costs of medical expenditures on a per capita level. The method employed in exploring to what extent the growing share of elderly individuals and income can explain the rise in medical expenditures is a multiple linear regression model. The expected results are that as the share of elderly individuals grows within Romania's population and similarly as income on a per capita bases rises, there will be a noticeable increase in per capita medical expenditures.
\end{abstract}

Key words: population ageing, population decline, demographic transition, healthcare expenditures, multiple linear regression

JEL Classification: C12, J11

Received December 23, 2019 / Revised January 19, 2020 / Accepted February 12, 2020 Corresponding author: Lucian Adrian Sala

University of Craiova, A.I.Cuza Street, No. 3, postal code 200585, Craiova, Romania

* PhD Student at the University of Craiova, Romania

E-mail: sala_lucian@yahoo.com 


\section{INTRODUCTION}

During the last decades, European Union Member States (EU MS) have gone through considerable changes in the age structure and size of their populations, this trend being reflected to a pronounced degree in Romania (European Commission, 2018).

The number of individuals with ages of 65 years and older has increased at a steady pace as a result of natural demographic transition factors presented in the scientific literature and recognised within scientific circles as population ageing and as one of the dominant demographic phenomena of the 21 st century (Feldstein, 2006).

Population ageing represents "the shift in the distribution of a country's population toward older ages" mainly due to "an increase in the population's mean or median age, a decline in the fraction of the population composed of children, or a rise in the fraction of the population that is elderly are all aspects of population ageing" (Weil, 2006, p. 3).

This demographic trend is expected to continue over the coming decades with adverse effects on social, economic and political spheres of influence, but most notably on the healthcare industry that may come under tremendous stress from a sharp increase in healthcare expenditures (HCE). The general perception is that as the share of individuals over the age of 65 years and older increases, so will per capita healthcare expenditures, as there exists a strong relationship between the two.

Similarly, as income per capita increases further due to economic development, the demand on behalf of the population for medical services will soar, adding further to costs.

In a study published by the Organisation for Economic Co-operation and Development (OECD), projections support the argument that gains in the share of elderly (65 years and older) may increase age-related social expenditures from an average of $19 \%$ of Gross Domestic Product to $26 \%$ by 2050 with increases in both long term HCE and public pension schemes (Dang et al., 2001). Comparable results are expected within Romania, where an increase in healthcare expenditures will be initiated by the restructuring efforts of governing bodies at the local level combined with demographic factors.

Population ageing will exert a direct effect on the level and structure of healthcare expenditures in Romania, due to the accelerated ageing process that is currently underway.

The focus of this paper is on analysing to what extent the rising share of the population ages 65 years and older and 80 years and older and Gross Domestic Product (GDP) per capita can explain the variation in HCE on a per capita basis within Romania's population using a multiple linear regression model. Through the utilisation of econometric techniques, the current paper introduces an element of novelty, supplementing the existing literature that covers the effects of ageing on healthcare in Romania.

The expected results are the existence of a strong relationship between healthcare expenditures on a per capita basis, the elderly share of the population and GDP on a per capita basis, demonstrated by way of correlation analysis. Equally, it is expected that the variation in healthcare expenditures will be explained to a high degree by the selected explanatory variables. Most notably the factors that contribute the most to the rise in HCE are expected to be the share of the population ages 80 years and older followed by GDP per capita. It is crucial to underline that the rise in healthcare expenditures in Romania's given its economic perspective may prove to be more burdensome than for other EU MS, thus it should take a more central role in decision-making processes at an administrative level. 
The paper is structured in five parts, with the first part covering the relevant scientific literature encompassing works on the relationship between population ageing and healthcare expenditures. The second part contains an overview of the present and future trends regarding population ageing and healthcare in Romania. In the third section, the reader is introduced to the applied research methodology and the selected data sets utilised in the analysis. The fourth section covers the application of the research methodology accompanied by an assessment of the results obtained in connection to similar research papers. The final section contains concluding remarks and observations based on the results obtained, including policy implications and future research directions.

\section{THE LINK BETWEEN POPULATION AgEING AND HEALTHCARE EXPENDITURES}

The behaviour and requirements of a population have historically been influenced by demographic changes, while technological breakthroughs, such as early detection of lifethreatening illness, non-invasive procedures and revolutionary treatments have helped to extend it (Thimbleby, 2013).

Demographic changes are shaped by two significant forces, most notably fluctuations in the mortality and fertility rate, that in certain combinations affect the development and structure of a population (Caselli \& Vallin, 1990).

The effects of a decline in the mortality rate in a population are much more complicated than the decrease in the fertility rate, where the decline in mortality among infants and children has the effect of rejuvenating the population and at older ages of increasing the proportion of adults in the population. Historically, declines in mortality among younger generations have led to gains in life expectancy, so a shift from high mortality rates to moderate mortality rates tends to change the structure of the population over time (Sanderson \& Scherbov, 2007).

Increases in life expectancy or longevity result in a more significant share of individuals surviving to advanced ages, this "life-changing" phenomenon leads to lower mortality rates in later stages of life (Beltrán-Sánchez et al., 2015; Dormont et al., 2010).

At present, the phenomenon of demographic ageing is expected to continue over the coming decades with adverse effects on social, economic and political spheres of influence, but most notably on the healthcare industry (HI) that may come under tremendous stress from a sharp increase in healthcare expenditures. The general perception is that as the share of individuals over the age of 65 years and older increases so will per capita HCE, as there exists a strong relationship between the two.

When taking into consideration more extended periods of time, it has been observed that HCE have a lower contribution in decreasing mortality in comparison to other factors such as nutrition and general public health measures (B. Harris, 2004). But in recent decades, the decline in mortality for older generations can be accredited in a more direct manner to the surge in HCE (Cutler et al., 2006).

The main factors driving the increase in HCE are the rise in income per capita and the share of the elderly individual's ages 65 years and older. Some additional factors that contribute to the rise in HCE include: the process of urbanisation; the number of hospitals; the number of physicians and nurses and the education level of individuals. 
Demographic ageing is linked to the rising number of illnesses disproportionately burdening older generations and to the additional years gained due to increases in longevity that are characterised by health impairments, which often lead to the limitation of mobility and work capacity (Shergold et al., 2015; WHO, 2011).

When examining the causes of increases in HCE over time, the main factors contributing can be grouped into two broad categories, namely social and individual factors that are interlinked and that exert a certain degree of influence on indvidualisation of healthcare services.

Socials factors can determine how access and care is provided to patients based on standard guidelines establish within a healthcare system, on medical breakthroughs and implementation of technologies and devices that might encourage individuals to access treatment (i.e. new drugs, robotic prosthetics, non-invasive surgery, etc.).

Likewise, the income and cost side of accessing treatment is fundamental when making health related choices (i.e. more expensive treatment may be scarcer and might require waiting lists).

The development of medical breakthroughs can be accredited to a desire to push the known limitations of science and to develop a better understanding of current medical conditions and of the human body. Thus, the desire to sustain medial progress can be seen as one of the main drivers of HCE growth through research and development (R\&D), producing new innovations that will at first have higher costs (Weisbrod, 1991).

Innovation through R\&D in the medical field has the effect over time of reducing costs, but this added benefit in return tends to increase the use of new medical devices resulting in spikes in cost at first (Morris, 2010). Medical novelties are centred around illnesses that affect for the most part elderly individuals; this can be seen as one of the main factors for a longer life span for this age group (Christensen et al., 2009).

The increase in technological advancements and implementation of revolutionary medical equipment is one of the primary factors driving the increases in medical expenditure. It has been argued that, due to technological factors, a "compression of morbidity" may occur, where individuals' lifespans are not greatly increased but the quality of healthy life would improve causing a decrease of medical expenditures since the proximity to death will become more manageable (Aristovnik, 2015; Chappell \& Hollander, 2011; Dormont et al., 2010).

A series of studies support the assertion that increasing medical expenditures can be more directly attributed to the rise in medical interventions and demand for emerging curative technologies in the pharmaceutical and medical fields as opposed to the general belief that the rising share of elderly individuals is the main driver of healthcare expenditure increases (Aristovnik, 2015; Baltagi et al., 2017; Xu et al., 2018).

Income per capita has a direct effect on HCE since health expenditures are "more sensitive to per capita income cyclical movements than to trend movements, and that the adjustment to income changes in those countries with a higher share of private health expenditure over total expenditure is faster" (Lago-Peñas et al., 2013, p. 1).

As income per capita fluctuates so will HCE, the intensity differing based on the size of disposable income, signalling that healthcare preferences will change as income per capita shifts (Lago-Peñas et al., 2013). 
On an individual basis, as income increases over time due to increases in productivity and the specialization of labour, so does the inclination to rely more heavily on healthcare providers (T. Getzen, 2000; T. E. Getzen, 1992).

The demand for prescription drugs is also likely to increase at a more rapid pace due to higher demand on behalf of elderly individuals. As individuals age, pharmaceutical drugs help to keep chronic diseases at a manageable level. However, as drug tolerance increases so does the need for higher dosages to help keep in check life-threatening conditions raising demand and costs.

Proximity to death plays an essential role in the latter stages of life, when prescription drug usage increases sharply as individual needs for pharmaceutical and pharmacological drugs rise (Kildemoes et al., 2006). Kildemoes et al. (2006) estimate that the latter two years of life are the costliest in terms of prescription drug usage and other HCE. Thus, it can be argued that age per se is not as an essential factor as proximity to death and the costs of dying are.

Individual factors form the second category and refer to issues that influence the utilisation of public or private healthcare services based on health, behaviour and demographical factors (age, gender, sex, status). These factors exert an influence on an individual basis or in synergy determining to a certain extent how individuals utilise available resources.

When considering an individual's health and behaviour, the medical literature suggests that a great deal of chronic diseases can be prevented by the decline and prevention of habits that include smoking, drinking and dietary change (Beltrán-Sánchez et al., 2015; WHO, 2007). Furthermore, increasing physical activities in addition to habit and dietary change may prove to be a cost-effective solution to lowering medical expenditures (Berwick et al., 2008; Chappell \& Hollander, 2011).

The World Health Organization has estimated that for every dollar invested in physical activity programs, a reduction of approximately 3.2 dollars can be achieved in medical expenditures over the course of life (Chappell \& Hollander, 2011; WHO, 2002, 2007). A similar investment has been observed to reduce medical expenditures between 6 and 8 dollars for every single dollar invested in health-related awareness campaigns (WHO, 2002).

When analysing the changes in medical expenditures per age groups, the share of costs attributed to young adults is lower than the cost of caring for elderly individuals. Then the main cause can be linked to the decreasing share of young adults in the total population due to lower birth rates and the increasing share of elderly individuals due to population ageing, offsetting medical costs to some degree (Beltrán-Sánchez et al., 2015).

Medical expenditures per age groups tend to increase at a much faster pace for individuals ages 50 years and older, due to an acceleration of the ageing process. A significant increase in HCE occurs for newborns due to medical expenditures associated with giving birth and primary medical care services available for infants and young adults (European Commission, 2018).

A mirroring of this tendency occurs for women that give birth where HCE tend to increase during childbirth, these costs peaking between the ages of 25 and 30 years. Another interesting aspect of age-related expenditures occurs after the age of 50 years where HCE for women are rising at a slower pace due to a better health condition than men (European Commission, 2018). 


\section{Population AgEING AND HEALTHCARE TRENDS In ROMANIA}

During the last three decades, Romania has faced a wave of changes within its demographic structure. These changes, for the most part, can be summarized as increases in life expectancy, declines in birth rates and an increasing proportion of old adults in the total population that can be summed up as population ageing (European Commission, 2017; Feldstein, 2006; Mihai, 2016).

According to the estimates of the National Institute of Statistics (INS), between 2017 2060 , the proportion of the population ages 60 years and older will grow at an accelerated pace. The number of centenaries will rise from 1,558 in 2015, to 5,094 in 2030, reaching about 22,587 centenarians alive by 2060 (INS, 2017).

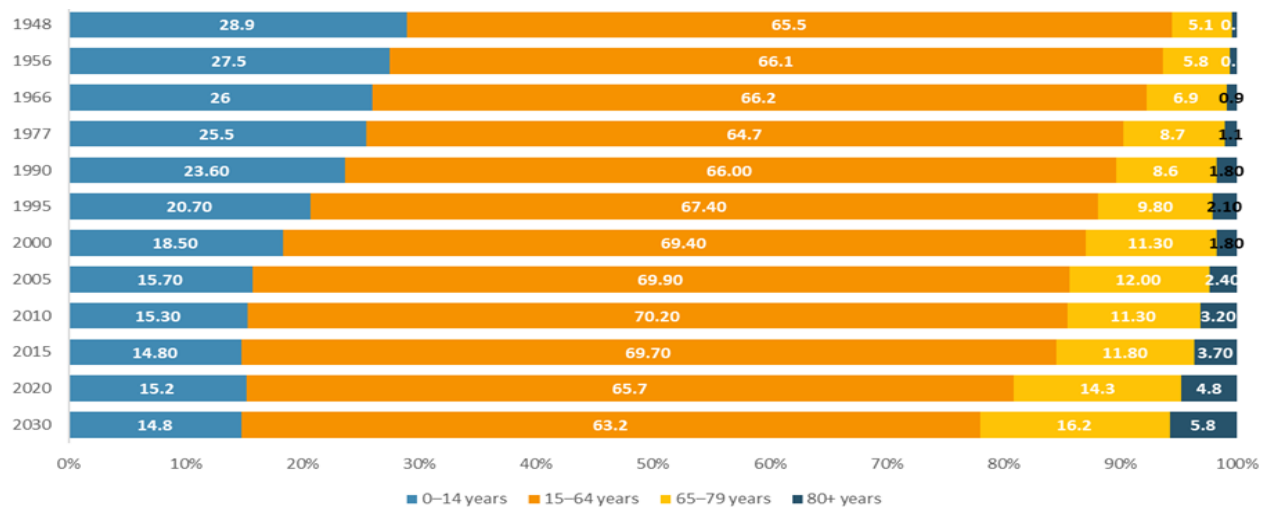

Fig. 1 Population by age groups projections, Romania Source: Own creation, based on Eurostat data

To further support these claims, we can observe in Figure 1, the decline in the share of individuals ages 0-14 years old in the period between 1948 and 2015 from 28.9\% to $15.7 \%$ and based on projections a further decline to $14.8 \%$ is expected by 2030 (INS, 2017). The opposite scenario is emerging for age groups between 65 and 79 years old and $80+$ years, that has increased at an accelerated pace, with projections for 2030 of $16.2 \%$ for individuals ages 65 to 79 years and 5.8\% for individuals age 80 years and above (INS, 2017).

Similarly, the old-age dependency ratio is expected to follow an upward trend, since the number of elderly individuals is expected to rise in comparison to individuals active in the labour market. Thus, the cost of social services and HCE will increase to match demand becoming costlier over the long run.

Between 1980 and 2010, the old-age dependency ratio has steadily grown to reflect the rising share of elderly individuals within the population and the declining size of the workforce. This process has been accelerated to some extent by the high levels of economic emigrants that have traversed to neighbouring countries for better working conditions and higher remuneration (Figure2) (Enache \& Pânzaru, 2012; Horváth \& Anghel, 2018).

The old-age dependency ratio (Figure 2) is expected to rise to $28.8 \%$ in 2020 and to $50 \%$ by the year 2050 , as the population ageing phenomenon advances. This expected increase will lead to increased stress on social security and healthcare programs in 
Romania due to sharp increases in expenditures (Cylus et al., 2018; Eurostat, 2019e; Thimbleby, 2013; Vladescu et al., 2016).

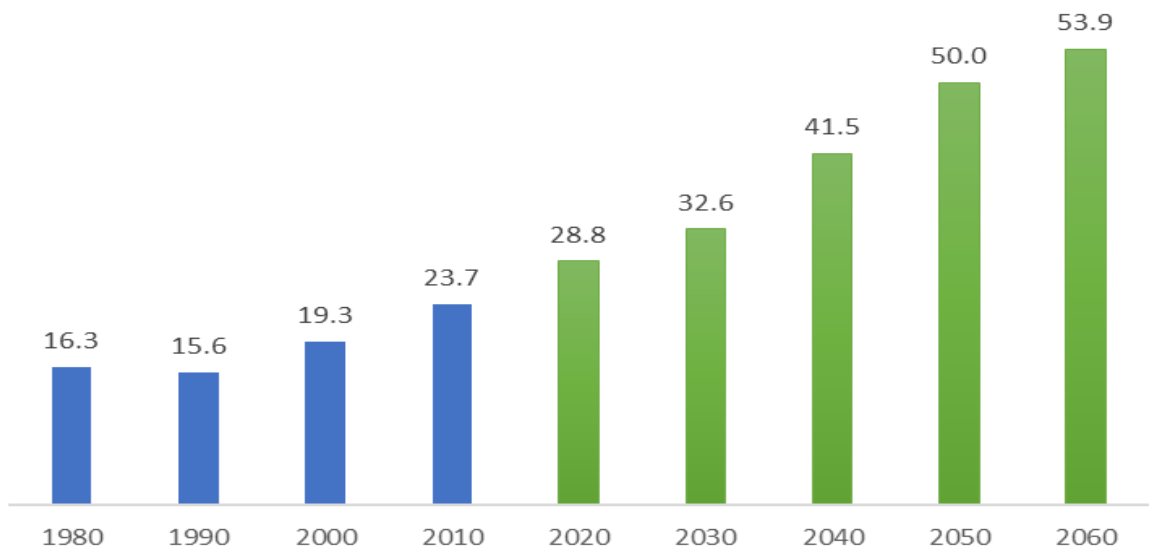

Fig. 2 Old-age dependency ratio projections, Romania Source: Own creation, based on Eurostat data

Life expectancy at birth in Romania has increased between 2000 and 2017, for males by 4 years from 61.7 years to 71.7 years and by 4.3 additional years from 74.8 years to 79.1 years for females in the same period of time (Eurostat, 2019d). However, despite these remarkable improvements in longevity, Romania is lagging behind the EU MS average for both men and women (Eurostat, 2019d).

A major cause of concern for Romania's healthcare system is the high level of infant mortality recorded, that is among the highest of EU MS with 6.7 deaths per 1000 live births in 2017, the number of infant mortalities recorded is almost double that of average figures recorded at the level of EU MS (Eurostat, 2019c).

Some of the main factors that lead to the early demise of individuals and that contribute to the increase in HCE are diseases of the cardiovascular system, different forms of cancer that have increased abruptly and infectious diseases, Romania having the highest incident of tuberculosis with a third of the cases presenting drug-resistant strains (Savin, 2014; Simionescu et al., 2019).

Other significant determinants of the health status of Romania's population represent the high consumption of alcohol that has increased both among men and women paired with the increasing cases of obesity among adults and children that raise the risk of cardiovascular diseases (Simionescu et al., 2019).

Healthcare expenditures per capita have grown from 236.10 Euros in 2000 to 1376.46 Euros in 2017- a near six-fold increase. However, Romania is positioned among the lowest places when it comes to healthcare expenditures on a per capita basis within the EU MS (Eurostat, 2019a). Healthcare expenditures as a percentage of GDP in Romania recorded a value of 5.16\% in 2017, representing the lowest level of all $28 \mathrm{EU}$ MS, below the average of 9.9\% (Eurostat, 2019b). 
Among some of the main factors contributing to the poor state of Romania's healthcare system is the lack of universal coverage for all citizens, where a discrepancy exists between access to and the quality of healthcare services in rural and urban areas.

These aspects can be traced back to the unsuccessful reform of the public health system and to political instability. In effect, due to the deficiency in medical infrastructure, staff and necessary medicine, Romania is slightly above the average when considering unmet medical and healthcare needs within the EU MS (Eurostat, 2019f).

A series of attempts have been made to decentralise the public health system with limited result. Currently, the Ministry of Health provides the general policy direction and administers regulatory oversite in an inefficient and burdensome manner, with local authorities responsible for the delivery of services (Vladescu et al., 2016).

To the effect of the information described above, it is acceptable to state that population ageing coupled with a poorly governed healthcare system produces a great deal of social and political implications.

To offset these effects a series of policy contributions on behalf of government bodies have been implemented in a gradual manner to help mitigate the effects of an ageing population (increasing the retirement age, legislative changes that are aimed at improving working conditions for women, changes in the public health insurance system, increasing investments in adult education programs) (Bodogai \& Cutler, 2014).

Despite the efforts and government measures focused at easing the transition to a "silver economy", Romania's population will continue to decline resulting in a significant restructuring within all age groups, from a regional to a national level, with significant declines in the number of newborns and increases in the share of older adults (Cristea \& Mitrica, 2016).

\section{MATERIALS AND METHODS}

In order to understand to what degree longevity and income explain the variation within healthcare expenditures in Romania, a series of data sets have been collected from official sources. The data collected for the purposes of econometric analysis (Table 1), have been gathered from Eurostat in the form of time series and contain data on healthcare expenditures per capita, the share of the population ages 65 years and older and 80 years and older and Gross Domestic Product per capita. The period is between 2000 and 2017, based on the availability of published data.

Table 1 Variable inputs for econometric model

\begin{tabular}{lll}
\hline Abbreviation & Description & Denominator \\
\hline spr_exp & Health expenditures per capita & Euros/capita \\
Pop_65 & Share of population age 65 years and over & Percentage (\%) \\
Pop_80 & Share of population age 80 years and over & Percentage (\%) \\
GDP_cap & Gross domestic product per capita & Euros/capita \\
\hline
\end{tabular}

Source: Own creation, based on Eurostat data

The utilisation of econometric techniques may help in shedding some light on the effects that a growing share of elderly individuals has on healthcare expenditures on a per 
capita basis. Linear regression methodology can be traced back to the $18^{\text {th }}$ Century, being applied by researchers as a least squared method approach in various fields from biology to astronomy (Draper \& Smith, 2014; Yan \& Su, 2009). Most notably in 1809, Carl Friedrich Gauss in his paper titled "Theoria Modus Corporum Coelestium" used a least squared approach to address the challenge of "determining from astronomical observations the orbits of bodies around the sun" (Chatterjee \& Simonoff, 2013; Yan \& Su, 2009).

Regression analysis can be defined as a "method to discover the relationship between one or more response variables (also called dependent variables, explained variables, predicted variables, or regressands, usually denoted by y) and the predictors (also called independent variables, explanatory variables, control variables, or regressors)" (Yan \& Su, 2009 , p. 2). Depending on the requirements and the number of variables, researchers can utilise a simple linear regression that models the linear relationship between two variables or a multiple linear regression that models the relationship between one dependent and more than one independent variables (Davison \& Tsai, 1992; Draper \& Smith, 2014).

The multiple linear regression model employed in this paper can be represented as follows (1.1) (Yan \& Su, 2009, p. 3):

$$
y_{i}=\beta_{0}+\beta_{1} x_{1 i}+\cdots+\beta_{p} x_{p i}+\varepsilon_{i}
$$

where:

y - dependent variable;

$x_{p i}$ - independent variable;

$\beta_{p}$ - parameter;

$\varepsilon_{i}-$ error.

One of the purposes of running a multiple regression analysis on a selected data sets is to determine the degree to which a set of independent variables can explain the variation within the dependent variable (Olive, 2017). When running a multiple linear regression analysis, a two-step process needs to be adopted that consists of, firstly, preparing the data sets, and secondly, employing a series of statistical tests meant to evaluate the validity and relative fit of the selected model (Weisberg, 2013; Yan \& Su, 2009).

The required tests will be applied in Stata 16 to assess the assumptions that "there should be homoscedasticity of residuals (equal error variances); there should be no multicollinearity; there should be no significant outliers, high leverage points or highly influential points; and the errors (residuals) should be approximately normally distributed" (Laerd Statistics, 2019; UCLA, 2019).

One of the first tests to be applied to the data sets is to verify the independence of variables. Thus, the Durbin-Watson test is computed to verifying the absence of 1 st-order correlation within the regression model. The Durbin-Watson test is computed utilising the following formula (1.2) (Yan \& Su, 2009, p. 235):

$$
D W=\frac{\sum_{i=2}^{n}\left(\hat{\varepsilon}_{i}-\hat{\varepsilon}_{i-1}\right)^{2}}{\sum_{i-1}^{n} \hat{\varepsilon}^{2}{ }_{i}}
$$

where $\hat{\varepsilon}_{i}=y_{i}-\hat{y}_{i}$ represents the residuals from the ordinary least squares fit. 


\section{RESULTS OF ANALYSIS}

In the process of running a multiple regression model, one of the first advised steps consists of plotting a scatter plot matrix as well as running a correlation analysis in order to asses the nature and strength of the bivariate relationships between the selected variables included in the model (Uyanık \& Güler, 2013). A scatter plot matrix permits visual inspections of the relationship between variables, helping to determine the existence of gaps and outliers within the data sets.

When analysing the scatter plot matrix in Figure 3, we can observe a close relationship between healthcare expenditures on a per capita basis, GDP per capita and the share of population ages 65 years and older and 80 years and older.

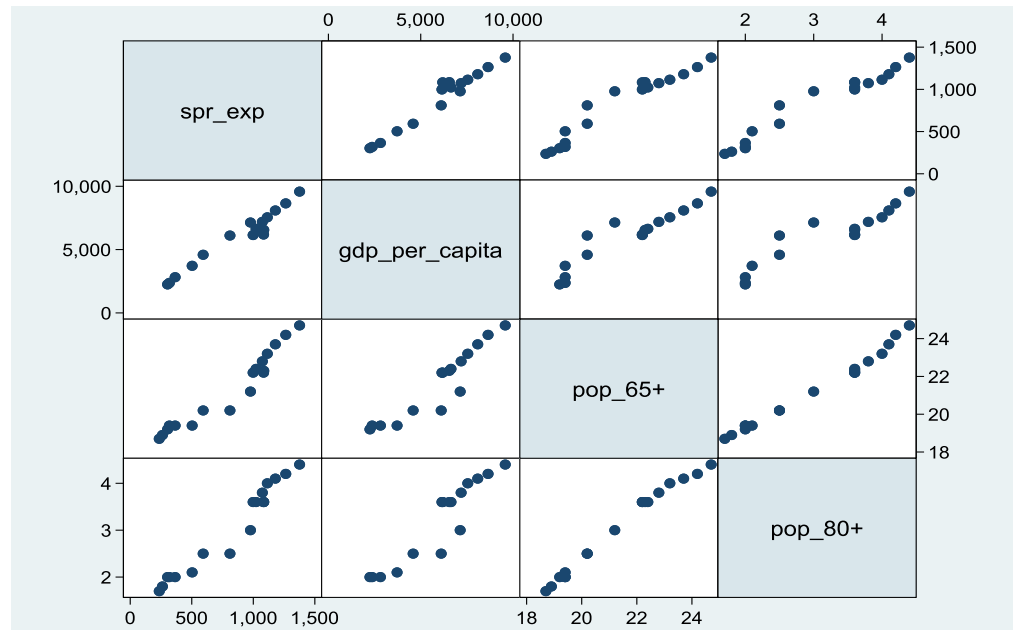

Fig. 3 Scatter plot matrix

Source: own processing in Stata 16

Similarly, we can observe the results obtained in the form of a correlation matrix (Table 2), as a result of running a Pearson correlation between the variables included in the model, where a strong relationship can be observed.

Table 2 Matrix of correlations

\begin{tabular}{lcccc}
\hline Variables & $(1)$ & $(2)$ & $(3)$ & $(4)$ \\
\hline (1) spr_exp & 1.000 & & & \\
(2) gdp_capita & 0.978 & 1.000 & & \\
(3) pop_65 & 0.956 & 0.937 & 1.000 & \\
(4) pop_80 & 0.968 & 0.933 & 0.991 & 1.000 \\
\hline \multicolumn{5}{c}{ Source: own processing in Stata 16 }
\end{tabular}

The rise in healthcare expenditures on a per capita basis in Romania can be explained to a great extent by the rise in GDP per capita and the share of population ages 65 years and older and 80 years and older through the results obtained by way of the linear regression model (Table 3). 
Table 3 Linear regression results

\begin{tabular}{|c|c|c|c|c|c|c|c|}
\hline spr_exp & Coef. & St.Err. & $\mathrm{t}$-value & p-value & {$[95 \%$ Conf } & Interval] & Sig \\
\hline gdp_cap & 0.101 & 0.014 & 7.41 & 0.000 & 0.072 & 0.131 & \\
\hline pop_65 & -135.635 & 45.693 & -2.97 & 0.012 & -235.192 & -36.079 & \\
\hline pop_80 & 430.944 & 93.176 & 4.63 & 0.001 & 227.931 & 633.958 & **** \\
\hline Constant & 1838.476 & 692.881 & 2.65 & 0.021 & 328.818 & 3348.134 & \\
\hline \multicolumn{2}{|c|}{ Mean dependent var } & 879.281 & \multicolumn{3}{|c|}{ SD dependent var } & \multicolumn{2}{|c|}{350.772} \\
\hline \multicolumn{2}{|l|}{ R-squared } & 0.989 & \multicolumn{3}{|c|}{ Number of observations } & \multicolumn{2}{|c|}{16.000} \\
\hline \multicolumn{2}{|l|}{ F-test } & 359.363 & \multicolumn{3}{|c|}{ Prob $>$ F } & \multicolumn{2}{|r|}{0.000} \\
\hline \multicolumn{2}{|c|}{ Akaike crit. (AIC) } & 167.752 & \multicolumn{3}{|c|}{ Bayesian crit. (BIC) } & \multicolumn{2}{|c|}{170.842} \\
\hline
\end{tabular}

The variables included in the multiple linear regression can explain with a high level of confidence the level of healthcare expenditures per capita in Romania, $F(3,12)=359.36$, $p$ $<.0005$, accounting for $98.90 \%$ of the variation in healthcare expenditures per capita with an adjusted value for $\mathrm{R}^{2}=98.62 \%$, which represents a high level according to Cohen (1988).

The linearity of the variables was assessed with the help of scatter plots of healthcare expenditures against GDP per capita, the share of individuals ages 65 years and older and the share of individuals ages 80 years and older, in each case a regression line has been superimposed.

After inspecting the resulting graphs, a linear relationship was confirmed in all cases. Further analysis indicated that residuals were normally distributed, and there is homoscedasticity (Draper \& Smith, 2014). To determine the independence of residuals, the Durbin-Watson test was applied with a result of 1.875 , indicating no autocorrelation (Durbin \& Watson, 1971).

For outlier detection, a standard visual inspection and a statistical analysis of studentized residuals were employed, confirming that no outliers were detected. The resulting predicted equation for the multiple regression model can be presented as follows (1.3):

$$
\operatorname{spr}_{\text {exp }}=1838.48+0.101 \times \mathrm{gdp}_{\text {per capita }}-135.64 \times \text { pop }_{65}+430.94 \times \text { pop }_{80}
$$

As can be observed in Table 3, GDP per capita is statistically significant at $\mathrm{p}<0.01$ with a value of 0.101 ; similar results have been observed in the scientific literature, where an increase in income does not necessarily translate to an equal increase in medical expenditures (Baltagi et al., 2017).

The main reason being that even with an increase in earning power, ageing individuals that are healthy will have only moderate increases in healthcare expenditures. In the presence of illness, expenditures will begin to increase and as the proximity to death window narrows, expenditures will begin to sharply increase for the final years of life (de Meijer et al., 2013; Gray, 2005)

An increase in the segment of the population ages 65 years and older seems to exert a negative effect at a significance level of $\mathrm{p}<0.05$, confirming previous studies that underlie increases in healthcare expenditure as a result of health and not necessarily of age (Gray, 2005). 
Finally, the variable that seems to contribute the most to healthcare expenditure per capita is the segment of the population ages 80 years and older at a significance level of $p<0.05$. The sharp increase in healthcare expenditures attributed to the segment of individuals ages 80 years and older has been observed in most developed countries and reflected in seminal research papers (de Meijer et al., 2013; Dormont et al., 2008; A. Harris \& Sharma, 2018). As this share of the population continues to grow, an expected rise in healthcare expenditures is expected, thus an adequate response is in order to help alleviate some of the pressure on the healthcare system (A. Harris \& Sharma, 2018; Vladescu et al., 2016).

Some of the main policy responses available include: a better management of resources within the public healthcare system; reducing the number of hospital days for elderly individuals in favour of out of hospital care when it is permitted; active measures that are aimed at reducing the risk of illness and that support an active and healthy ageing process; awareness campaigns through the use of mass media targeting the most common causes of morbidity and disability (diet, drinking, smoking, lack of physical exercise) (Rechel et al., 2009).

\section{CONCLUSION}

Population ageing presents a set of formidable provocations on the healthcare sector, driving innovation of new technologies through $R \& D$ but at a greater cost for society over the long run. As more investment capital flows into R\&D, economic growth may be spurred in the medical field and other adjacent fields like electronics and the information technology industry. However, this capital transfer will come at the cost of other developments in industrial production, transportation, education and other key branches of the economy. When trying to understand how healthcare expenditures will change over the coming periods, it becomes difficult to predict a certain outcome due to the lack of a well-defined framework since it becomes unclear which demographic aspects have the sturdiest effects on healthcare expenditures.

The variables with most influence being the number of individuals that surpass a certain age, the number of individuals that suffer from illness or disability and the expected number of years that individuals cope with an illness or disability until demise also known as "time till death" (OECD, 2019).

One of the key policies adopted at a global level has been the active ageing policy, introduced in 2002 by the World Health Organisation, that has been established with the purpose of empowering individuals to pursue lifelong goals of self-improvement and societal contribution to the highest extent, under the premise of good health, high mobility and peak mental performance. The concept of active ageing has been further refined by healthy ageing policies and objectives aimed at "emphasising the need for action across multiple sectors and enabling older people to remain a resource to their families, communities and economies" (WHO, 2019).

Healthy ageing can be defined as "the process of developing and maintaining the functional ability that enables wellbeing in older age" (WHO, 2019). These measures introduced some critical aspects of a healthier lifestyle, having been adopted to some extent by EU MS but changing health and work habits paradigms will require a more extensive effort on behalf of member states. 
The implementation of active ageing and healthy ageing measures requires "constant policy rethinking, adequate strategies, measures and tools for the active ageing population support" with the objective of integrating elderly individuals in all meaningful areas of life (Thalassinos et al., 2019, p. 9). Adopting and integrating active ageing and healthy ageing policies in Romania will require a long-term commitment with involvement on behalf of public and private partners in a variety of areas from environmental to economic, health and social services.

Good stewardship of the healthcare system and healthy living programs represent a big part of the healthy ageing agenda, where individuals are encouraged to maintain and improve the quality of life by exercising more, changing dietary habits, reducing alcohol consumption and smoking (WHO, 2007).

In regards to policy implication, the most important measures implemented to curb the effects of population ageing on social security services and healthcare providers has been the decision to increase the mandatory retirement age. This decision has the added benefit of supporting the workforce through a longer working life on behalf of employees. Thus, since a bigger share of older individuals is involved in an active way in the workforce for longer periods of time, the balance will shift in favour of active individuals, lowering the dependency ratio for the elderly.

Declines in healthcare expenditures can be further supported by informal caregiving offered by family members to elderly individuals in need of assistance. Thus, as caregiving is transferred to local communities, the cost will tend to decrease in favour of public care facilities and hospitals lowering the overall burden on public healthcare services (Chappell \& Hollander, 2011; WHO, 2002). Informal caregiving must be supported by well-governed and implemented policies and must be done more directly only with the support and guidance of healthcare professional (Chappell \& Hollander, 2011; Simionescu et al., 2019).

Research limitations encompass the limited data sets and a general lack of statistical information available, limiting the possibility of more in-depth analysis. Likewise, the lack of a well-defined framework within the healthcare industry makes it difficult to evaluate and predict how healthcare expenditures might react to shift in the population structure. Based on current results, the application of a vector autoregression model (VAR) might help in assessing how healthcare expenditures may respond to changes in the population structure due to the ageing phenomenon and GDP per capita.

Acknowledgement: This work was supported by the grant POCU/380/6/13/123990, co-financed by the European Social Fund within the Sectorial Operational Program Human Capital 2014 - 2020.

\section{REFERENCES}

Aristovnik, A. (2015). Efficiency of the Healthcare Sector in the EU-28 at the Regional Level. 9.

Baltagi, B. H., Lagravinese, R., Moscone, F., \& Tosetti, E. (2017). Health Care Expenditure and Income: A Global Perspective. Health Economics, 26(7), 863-874. https://doi.org/10.1002/hec.3424

Beltrán-Sánchez, H., Soneji, S., \& Crimmins, E. M. (2015). Past, Present, and Future of Healthy Life Expectancy. Cold Spring Harbor Perspectives in Medicine, 5(11). https://doi.org/10.1101/cshperspect.a025957

Berwick, D. M., Nolan, T. W., \& Whittington, J. (2008). The Triple Aim: Care, Health, And Cost. Health Affairs, 27(3), 759-769. https://doi.org/10.1377/hlthaff.27.3.759

Bodogai, S. I., \& Cutler, S. J. (2014). Aging in Romania: Research and Public Policy. The Gerontologist, 54(2), 147-152. https://doi.org/10.1093/geront/gnt080 
Caselli, G., \& Vallin, J. (1990). Mortality and Population Ageing. European Journal of Population / Revue Européenne de Démographie, 6(1), 1-25. JSTOR.

Chappell, N., \& Hollander, M. (2011). An Evidence-Based Policy Prescription for an Aging Population. HealthcarePapers, 11(1), 8-18. https://doi.org/10.12927/hcpap.2011.22246

Chatterjee, S., \& Simonoff, J. S. (2013). Handbook of regression analysis. Wiley.

Christensen, K., Doblhammer, G., Rau, R., \& Vaupel, J. W. (2009). Ageing populations: The challenges ahead. Lancet (London, England), 374(9696), 1196-1208. https://doi.org/10.1016/S0140-6736(09)61460-4

Cristea, M., \& Mitrica, A. (2016). Global Ageing: Do Privately Managed Pension Funds Represent a Long Term Alternative for the Romanian Pension System? Empirical Research. Romanian Journal of Political Science, 16(1), 63.

Cutler, D., Deaton, A., \& Lleras-Muney, A. (2006). The Determinants of Mortality. Journal of Economic Perspectives, 20(3), 97-120. https://doi.org/10.1257/jep.20.3.97

Cylus, J., Normand, C., \& Figueras, J. (2018). Will Population Ageing Spell the End of the Welfare State? A review of evidence and policy options. WHO Regional Office for Europe, 43.

Dang, T.-T., Antolín, P., \& Oxley, H. (2001). Fiscal Implications of Ageing: Projections of Age-Related Spending. https://doi.org/10.1787/503643006287

Davison, A. C., \& Tsai, C.-L. (1992). Regression Model Diagnostics. International Statistical Review / Revue Internationale de Statistique, 60(3), 337-353. https://doi.org/10.2307/1403682

de Meijer, C., Wouterse, B., Polder, J., \& Koopmanschap, M. (2013). The effect of population aging on health expenditure growth: A critical review. European Journal of Ageing, 10(4), 353-361. https://doi.org/ 10.1007/s10433-013-0280-x

Dormont, B., Martins, J. O., Pelgrin, F., \& Suhrcke, M. (2010). Health expenditures, longevity and growth. In Ageing, Health, and Productivity: The Economics of Increased Life Expectancy. In The Growth of Health Expenditures: Ageing vs. Technological Progress. Oxford University Press. https://doi.org/10.1093/acprof:oso/ 9780199587131.001.0001

Dormont, B., Oliveira Martins, J., Pelgrin, F., \& Suhrcke, M. (2008). Health Expenditures, Longevity and Growth. SSRN Electronic Journal. https://doi.org/10.2139/ssrn.1130315

Draper, N., \& Smith, H. (2014). Applied Regression Analysis, 3rd Edition. Wiley. https://www.wiley.com/enus/Applied+Regression+Analysis\%2C+3rd+Edition-p-9781118625682

Durbin, J., \& Watson, G. S. (1971). Testing for serial correlation in least squares regression.III. Biometrika, 58(1), 1-19. https://doi.org/10.1093/biomet/58.1.1

Enache, C., \& Pânzaru, C. (2012). Romanian Migration Flows In European Countries: Does social security matter? 11.

European Commission. (2017). The 2018 ageing report: Underlying assumptions and projection methodologies. https://ec.europa.eu/info/sites/info/files/economy-finance/ip065_en.pdf

European Commission. (2018). The 2018 ageing report economic \& budgetary projections for the $28 \mathrm{EU}$ Member States (2016-2070). https://ec.europa.eu/info/publications/economy-finance/2018-ageing-reporteconomic-and-budgetary-projections-eu-member-states-2016-2070_en

Eurostat. (2019a). Health care expenditure in the EU. https://ec.europa.eu/eurostat/web/products-eurostatnews/-/DDN-20181129-2

Eurostat. (2019b). Healthcare expenditure across the EU: 10\% of GDP. https://ec.europa.eu/eurostat/web/ products-eurostat-news/-/DDN-20190904-1

Eurostat. (2019c). Infant mortality rates-Eurostat. https://ec.europa.eu/eurostat/web/products-datasets//demo_minfind

Eurostat. (2019d). Life expectancy at birth by sex-Eurostat. https://ec.europa.eu/eurostat/web/productsdatasets/product?code=sdg_03_10

Eurostat. (2019e). Record high old-age dependency ratio in the EU. https://ec.europa.eu/eurostat/web/ products-eurostat-news/-/DDN-20180508-1

Eurostat. (2019f). Unmet health care needs statistics - Statistics Explained. https://ec.europa.eu/eurostat/ statistics-explained/index.php/Unmet_health_care_needs_statistics

Feldstein, M. S. (2006). The Effects of the Ageing European Population on Economic Growth and Budgets: Implications for Immigration and Other Policies (Working Paper No. 12736). National Bureau of Economic Research. https://doi.org/10.3386/w12736

Getzen, T. (2000). Health Care is an Individual Necessity and a National Luxury: Applying Multilevel Decision Models to the Analysis of Health Care Expenditures. Journal of Health Economics, 19, 259-270. https://doi.org/10.1016/S0167-6296(99)00032-6

Getzen, T. E. (1992). Population Aging and the Growth of Health Expenditures. Journal of Gerontology, 47(3), S98-S104. https://doi.org/10.1093/geronj/47.3.S98 
Gray, A. (2005). Population Ageing and Health Care Expenditure. Oxford Institute of Ageing, Ageing Horizons(2), 15-20.

Harris, A., \& Sharma, A. (2018). Estimating the future health and aged care expenditure in Australia with changes in morbidity. PLoS ONE, 13(8). https://doi.org/10.1371/journal.pone.0201697

Harris, B. (2004). Public Health, Nutrition, and the Decline of Mortality: The McKeown Thesis Revisited. Social History of Medicine - SOC HIST MED, 17, 379-407. https://doi.org/10.1093/shm/17.3.379

Horváth, I., \& Anghel, R. (2018). Migration and Its Consequences for Romania.

INS. (2017). Proiectarea populației României, în profil teritorial. La orizonul anului 2060. Editura Insitutului Național de Statistică. http://www.insse.ro/cms/en/content/projection-romanian-population-horizon-2060

Kildemoes, H., Christiansen, T., Gyrd-Hansen, D., Kristiansen, I., \& Andersen, M. (2006). The impact of population aging on future Danish drug expenditure. Health Policy (Amsterdam, Netherlands), 75, 298311. https://doi.org/10.1016/j.healthpol.2005.03.013

Laerd Statistics. (2019). How to perform a Multiple Regression Analysis in Stata | Laerd Statistics. https://statistics.laerd.com/stata-tutorials/multiple-regression-using-stata.php

Lago-Peñas, S., Cantarero-Prieto, D., \& Blázquez-Fernández, C. (2013). On the relationship between GDP and health care expenditure: A new look -. Economic Modelling, 32, 124-129. https://doi.org/doi.org/ 10.1016/j.econmod.2013.01.021

Mihai, C. (2016). Dimensions of population ageing in Romania. Agricultura - Ştiinţă Şi Practică, 3, 19-81.

Morris, J. (2010). Human rights and healthcare: Changing the culture. Age and Ageing, 39(5), 525-527. https://doi.org/10.1093/ageing/afq094

Olive, D. J. (2017). Linear Regression. Springer.

Rechel, B., Doyle, Y., Grundy, E., \& McKee, M. (2009). How can health systems respond to population ageing? Health Systems and Policy Analisys, 10, 43.

Sanderson, W. C., \& Scherbov, S. (2007). A new perspective on population aging. Demographic Research, 16(2), 27-58. https://doi.org/10.4054/DemRes.2007.16.2

Savin, S. (2014). Cancer Country Profile. 2.

Shergold, I., Lyons, G., \& Hubers, C. (2015). Future mobility in an ageing society - Where are we heading? Journal of Transport \& Health, 2(1), 86-94. https://doi.org/10.1016/j.jth.2014.10.005

Simionescu, M., Bilan, S., Gavurova, B., \& Bordea, E.-N. (2019). Health Policies in Romania to Reduce the Mortality Caused by Cardiovascular Diseases. International Journal of Environmental Research and Public Health, 16(17), 3080. https://doi.org/10.3390/ijerph16173080

Thalassinos, E., Cristea, M., \& Noja, G. G. (2019). Measuring active ageing within the European Union: Implications on economic development. Equilibrium. Quarterly Journal of Economics and Economic Policy, 14(4), 591-609. https://doi.org/10.24136/eq.2019.028

Thimbleby, H. (2013). Technology and the Future of Healthcare. Journal of Public Health Research, 2(3). https://doi.org/10.4081/jphr.2013.e28

UCLA. (2019). Introduction to Regression with SPSS Lesson 2: SPSS Regression Diagnostics. https://stats.idre.ucla.edu/spss/seminars/introduction-to-regression-with-spss/introreg-lesson2/

Uyanık, G. K., \& Güler, N. (2013). A Study on Multiple Linear Regression Analysis. Procedia - Social and Behavioral Sciences, 106, 234-240. https://doi.org/10.1016/j.sbspro.2013.12.027

Vladescu, C., Scîntee, S. G., Olsavszky, V., Hernández-Quevedo, C., \& Sagan, A. (2016). Health Systems in Transition. Romania, Health system review. 18(4), 203.

Weil, D. N. (2006). Population Aging (Working Paper No. 12147). National Bureau of Economic Research. https://doi.org/10.3386/w12147

Weisberg, S. (2013). Applied Linear Regression, 4th Edition. Wiley. https://www.wiley.com/enus/Applied+Linear+Regression\%2C+4th+Edition-p-9781118386088

Weisbrod, B. (1991). The Health Care Quadrilemma: An Essay on Technological Change, Insurance, Quality of Care, and Cost Containment. Journal of Economic Literature, 29, 523-552.

WHO. (2002). WHO | Active ageing: A policy framework. http://www.who.int/ageing/publications/active_ ageing/en/

WHO (Ed.). (2007). Global age-friendly cities: A guide. World Health Organization.

WHO. (2011). Global Health and Aging (p. 32). https://www.who.int/ageing/publications/global_health.pdf

WHO. (2019). WHO | What is Healthy Ageing? WHO. http://www.who.int/ageing/healthy-ageing/en/

Xu, K., Soucat, A., Kutzin, J., Brindley, C., Maele, N., Toure, H., Garcia, M., Li, D., Barroy, H., Flores, G., Roubal, T., Indikadahena, C., Cherilova, V., \& Siroka, A. (2018). Public Spending on Health: A Closer Look at Global Trends. Geneva: World Health Organization.

Yan, X., \& Su, X. (2009). Linear regression analysis: Theory and computing. World Scientific. 


\section{ODNOS IZMEĐU STARENJA POPULACIJE I MEDICINSKIH TROŠKOVA U RUMUNIJI}

Rezime. Sa skorašnjim razvojem na polju medicine i bržim pristupom medicinskim stručnjacima $i$ negovateljima, uz dodatak boljeg obrazovanja i višeg nivoa highene, dužina života se u Rumuniji stalno povećava, i za muškarce $i$ za žene. Sa medicinske tačke gledišta, ovo je izvanredno postignuće kad se uporedi sa prošlim dekadama kada je očekivani životni vek bio mnogo kraći nego u poslednje vreme. Duži životni vek će automatski, u najvećem broju slučajeva, imati $i$ neželjeni efekat povećane potrošnje na medicinske usluge od strane države da bi se starijima omogućio bolji kvalitet života. Stoga, javni zdravstveni sistem će biti izložen dodatnom pritisku od strane pružalaca zdravstvenih usluga da bi se starijima pružile kvalitetnije usluge. Ovaj rad ima za cilj da istraži nivo uticaja koji godine i prihodi imaju na povećanje medicinskih troškova na per capita nivou. Metoda koja je korišćena u istraživanju do kog nivoa rastući deo starijih i prihoda mogu da objasne povećanje medicinskih troškova je višestruki model linerane regresije. Očekivani rezultati su da procenat starijih osoba raste u populaciji Rumunije i slično tome, kako prihod na per capita nivou raste, javiće se $i$ vidno povećanje u medicinskim troškovima per capita.

Ključne reči: starenje popuilacije, opadanje populacije, demografska tranzicija, zdravstveni troškovi, višestruka linearna regresija. 